\title{
Correction of rectal sacculation through lateral resection in dogs with perineal hernia - technique description
}

\author{
[Correção de saculação retal por meio de ressecção lateral em cães com \\ hérnia perineal - descrição da técnica] \\ P.C. Moraes ${ }^{1}$, N.M. Zanetti ${ }^{2}$, C.P. Burger ${ }^{2}$, A.E.W.B. Meirelles ${ }^{2}$, \\ J.C. Canola ${ }^{3}$, J.G.M.P. Isola ${ }^{2}$ \\ ${ }^{1}$ Universidade Estadual Julio de Mesquita filho - UNESP-FCAV - Jaboticabal, SP \\ ${ }^{2}$ Programa de pós graduação - Universidade Estadual Julio de Mesquita filho - UNESP-FCAV - Jaboticabal, SP \\ ${ }^{3}$ Universidade Estadual Julio de Mesquita filho - UNESP-FCAV - Jaboticabal, SP
}

\begin{abstract}
The occurrence of perineal hernias in dogs during routine clinical surgery is frequent. The coexistence of rectal diseases that go undiagnosed or are not correctly treated can cause recurrence and postoperative complications. The objective of this report is to describe a surgical technique for treatment of rectal sacculation through lateral resection in dogs with perineal hernia, whereby restoring the rectal integrity.
\end{abstract}

Key words: dog, perineal hernia, rectal disease

\section{RESUMO}

A ocorrência de hérnias perineais em cães na rotina clínica cirúrgica é frequente. A coexistência de doenças do reto não diagnosticadas ou não tratadas corretamente pode causar recidiva e complicações pósoperatórias. Este relato tem como objetivo descrever uma técnica cirúrgica para o tratamento de saculação retal por meio de ressecção lateral em cães com hérnia perineal, com restabelecimento da integridade retal.

Palavras-chave: cão, hérnia perineal, afecção retal

\section{INTRODUCTION}

Perineal hernias are characterized by rupture of one or more pelvic cavity muscles (Ferreira and Delgado, 2003; Costa Neto et al., 2006) due to alterations of the pelvic diaphragm. Caudal displacement of anatomical structures, such as rectal, pelvic or abdominal contents, indicated by swelling of the perineal region (Welches et al., 1992; Costa Neto et al., 2006; Fossum et al., 2008) lead to persistent rectal distention and impaired defecation (Fossum et al., 2008). The exact cause of muscle weakness is unknown but some factors have been proposed, such as neurogenic or senile muscle atrophy, myopathies, prostate enlargement, hormonal alterations and chronic constipation (Hedlund, 2002; Bellenger and Canfield, 2003; Sein III, 2004).

The concomitant emergence of rectal sacculation is very common, especially in chronic hernias

Recebido em 28 de novembro de 2011

Aceito em 4 de dezembro de 2012

E-mail: pcastromoraes@yahoo.com.br
(Krahwenkel, 1983; Ferreira and Delgado, 2003). It can be reported isolated or coexisting with perineal hernia. Krahwinkel (1983) suggests that rectal anomalies are secondary to perineal hernias. According to many authors (Burrows and Harvey, 1973; Orsher, 1986), this condition is severe and, if not properly treated, can lead to feces impaction in the sacculation and difficulty to defecate; consequently, there can be a loss of repair of the ventral herniorrhaphy and these will predispose to recurrence of the herniation.

This disease is diagnosed based on history, clinical signs, physical examination and radiographic findings (Dean and Bojrab, 1996). Rectal palpation is the most important step in a physical examination. Feces are removed manually and the index finger is used to verify the existence and degree of anomaly, such as rectal deviations, sacculations and diverticula (Dieterich, 1975), as well as to classify the degree of atrophy/pelvic diaphragm muscle separation, and dimension/location of prostate (Bojrab and Toomey, 1981). 
Survey radiographs should be performed to evaluate the extension of rectal dilation and to determine correct radiographic exposure technique and adequate patient preparation before contrast study. Patients should fast for 24 to 36 hours and a cleansing enema should be performed to empty the colon. Next, a barium enema radiographic study is achieved by administering room temperature barium through an inflatable cuffed catheter placed in the very distal rectum and filled by gravity, using a volume varying from 7 to $15 \mathrm{ml}$ per kilogram of body weight (Bojrab and Toomey, 1981; Schwarz and Biery, 2007). Radiographic findings of rectal dilation or sacculation are characterized by an external and intact pouch on the rectum wall (Bojrab and Toomey, 1981). Ventrodorsal projection is the best to observe sacculation and rectal flexures (Bellenger and Canfiel, 1998), and these structures are differentiated during surgery (Bojrab and Toomey, 1981).

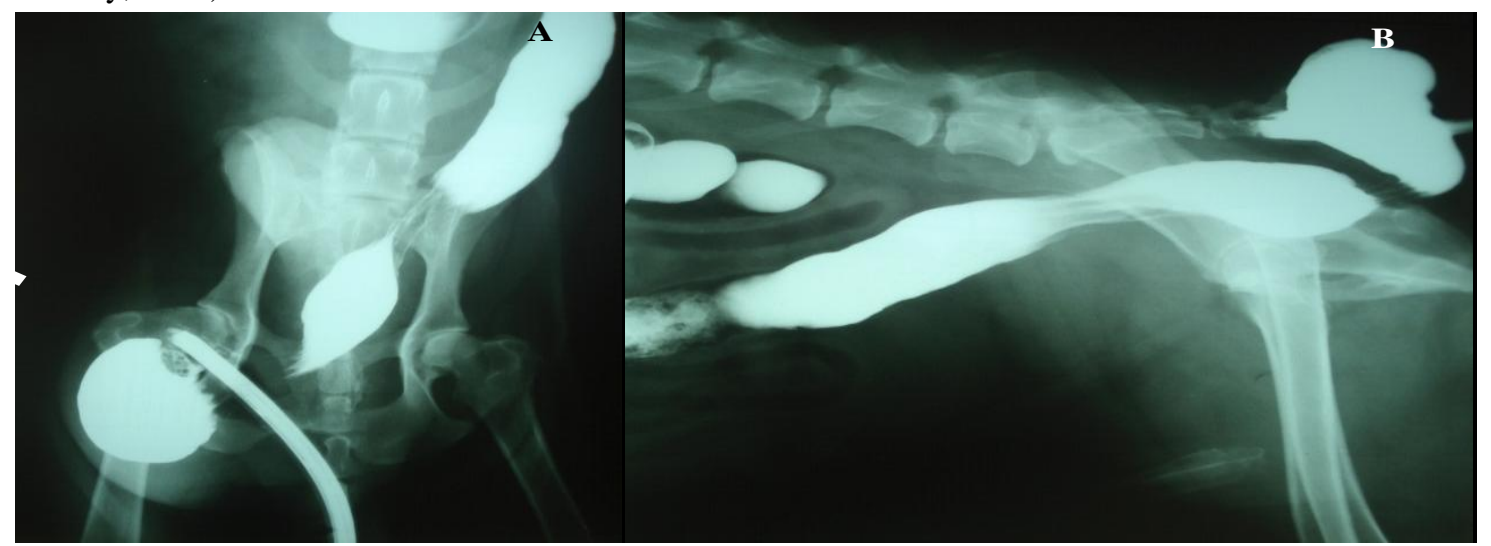

Figure 1. Radiographic image of a dog with perineal hernia and the presence of rectal sacculation in ventrodorsal (A) and right lateral (B) projections. Barium enema shows looseness on the caudal portion of the rectum (arrows).

After liberally clipping the hair from the region, a lubricated syringe is inserted into the anus to help in identifying the rectal lumen during surgery (Figure 2). A skin incision is performed on the affected side, parallel to the anus and extending ventrally to the ischial tuberosity. After dissection of the subcutaneous tissue, the hernia contents are reduced and maintained with gauze and a Kocher forceps. The rectum and rectal sacculation are identified through digital palpation. The rectal sacculation is retracted and clamped with atraumatic intestinal forceps taking care to protect the rectal lumen, which can be identified by the presence of the syringe
Therefore, the objective of this report is to describe a technique for the correction of rectal sacculation used at the Governador Laudo Natel Veterinary Hospital at São Paulo State University- UNESP in Jaboticabal and, in view of the positive results achieved, make it available to veterinary surgeons worldwide.

\section{MATERIALS AND METHODS}

After thorough physical examination to confirm the presence of rectal sacculation, contrast radiography (barium enema) is performed with special attention to the ventrodorsal projection, in which the rectal alteration can be identified (Figure 1). After diagnosis confirmation the patient is submitted to surgery. The animal is positioned in sternal recumbency on the operating table, with hind limbs pending. The table should be slightly inclined so the perineal region remains elevated. 


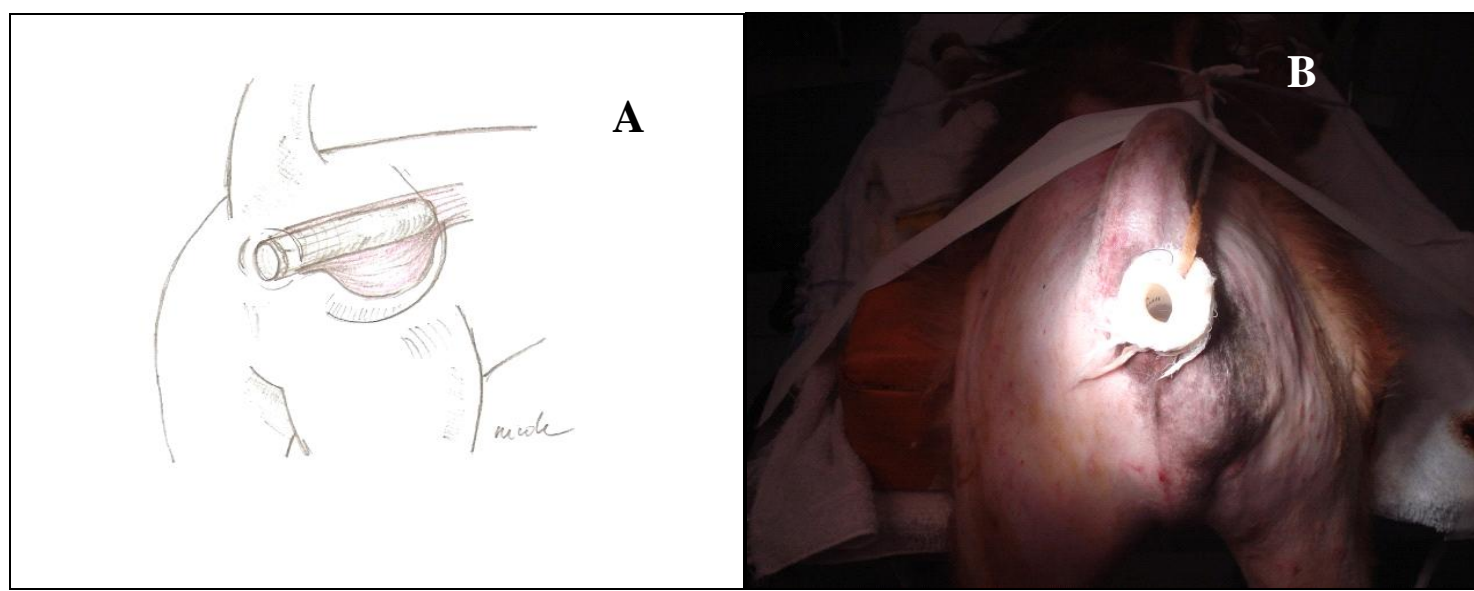

Figure 2. Illustrative drawing (A) and photographic image (B) of a dog with perineal hernia and rectal sacculation, positioned on operating table. The arrow indicates the lubricated syringe inserted in the rectum.

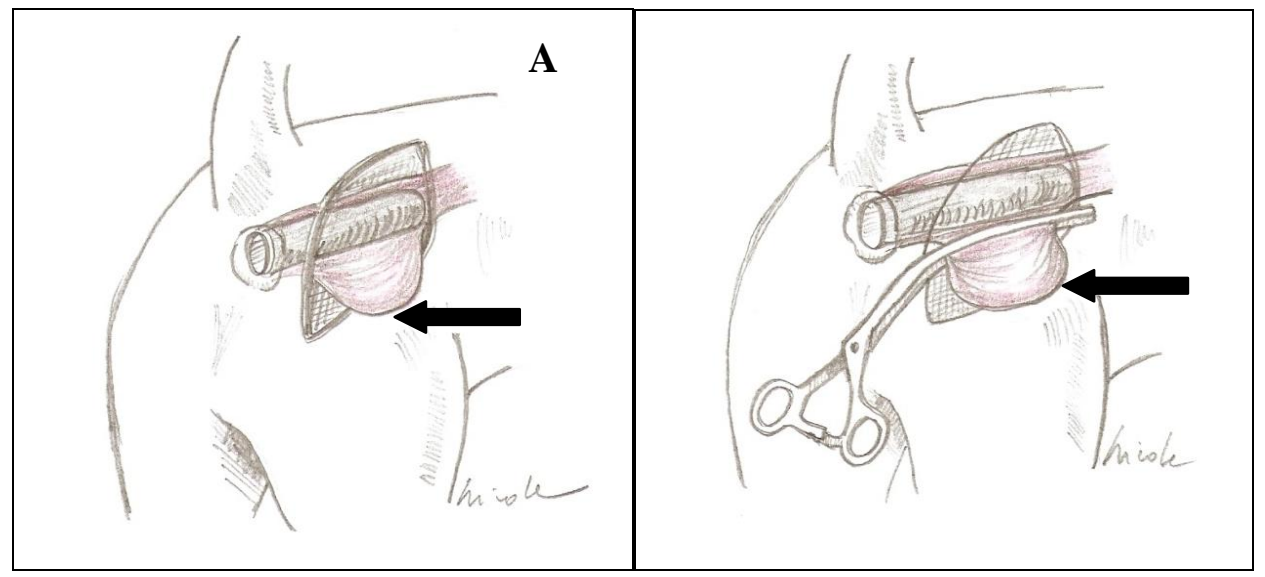

B

Figure 3. Illustrative drawing of rectal sacculation of a dog. In A, the syringe is inserted in the rectum to facilitate identification of rectal abnormality (arrow). In B, the arrow indicates the placement of atraumatic intestinal forceps delimiting the portion to be resected.

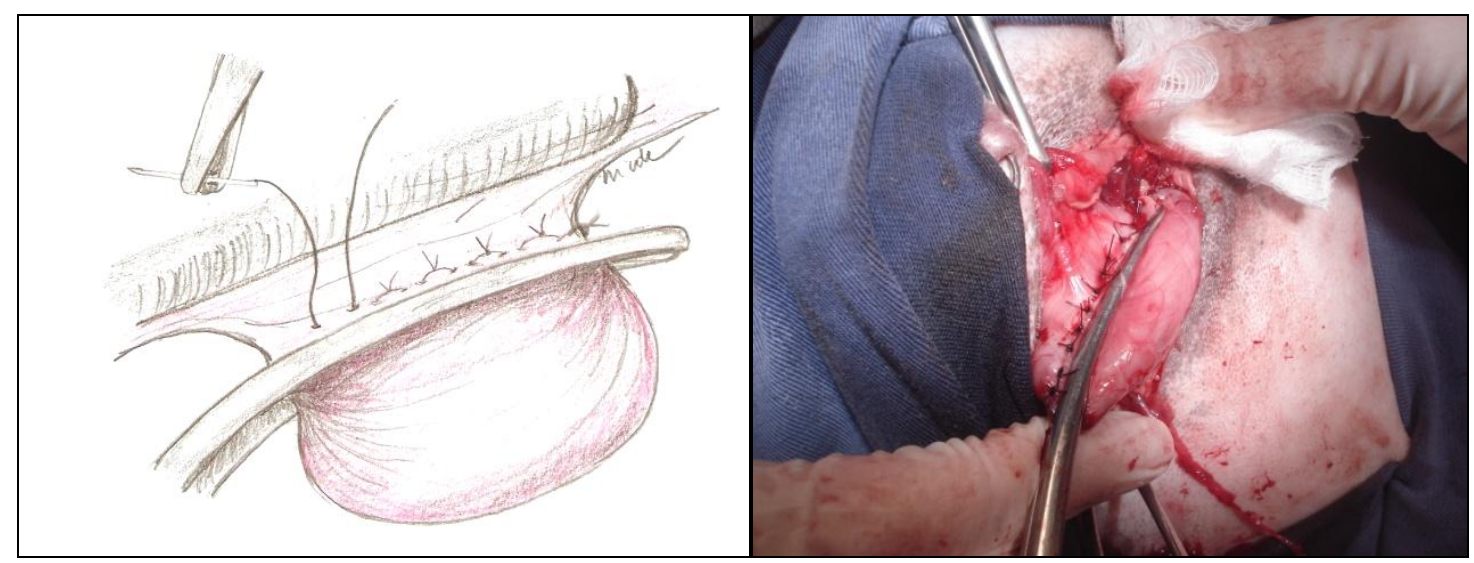

Figure 4. Illustrative drawing (A) and photographic image (B) of Wolff suture used for resection of rectal sacculation after placement of atraumatic intestinal forceps of a dog. 


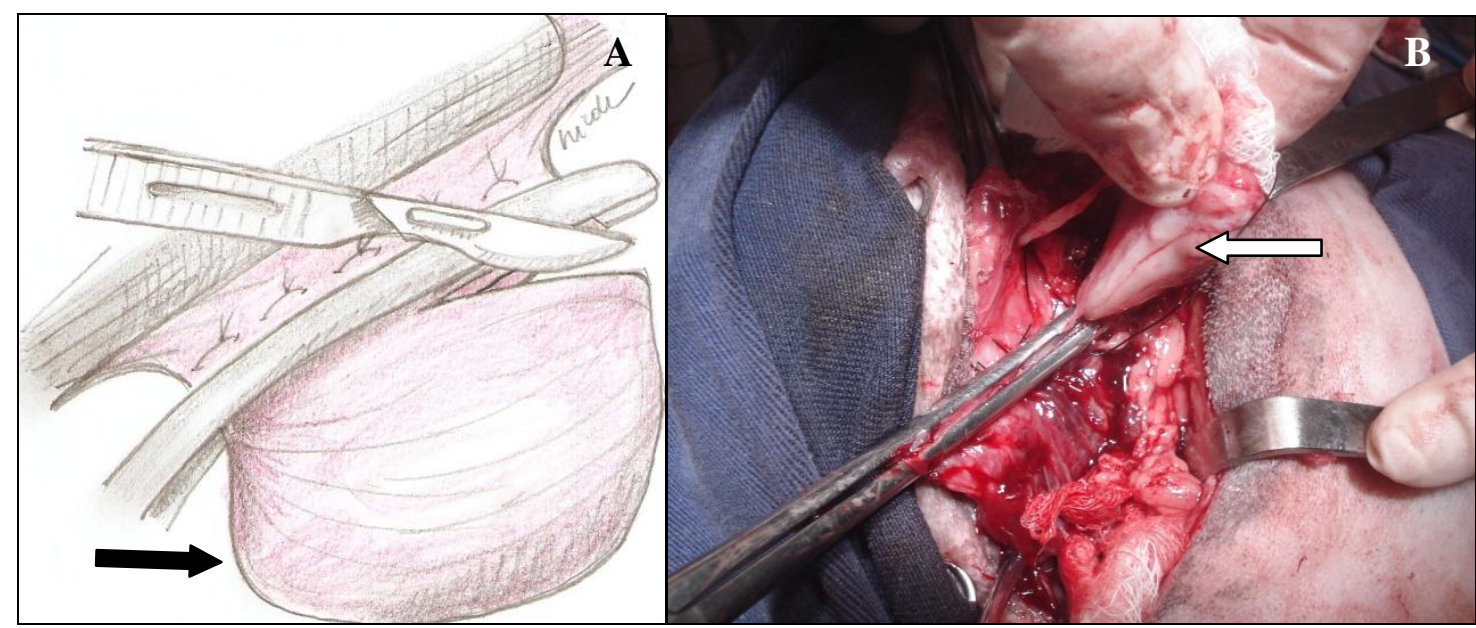

Figure 5. Illustrative drawing (A) and photographic image (B) at the moment of resection of rectal sacculation (arrow), after completion of Wolff suture on a dog.

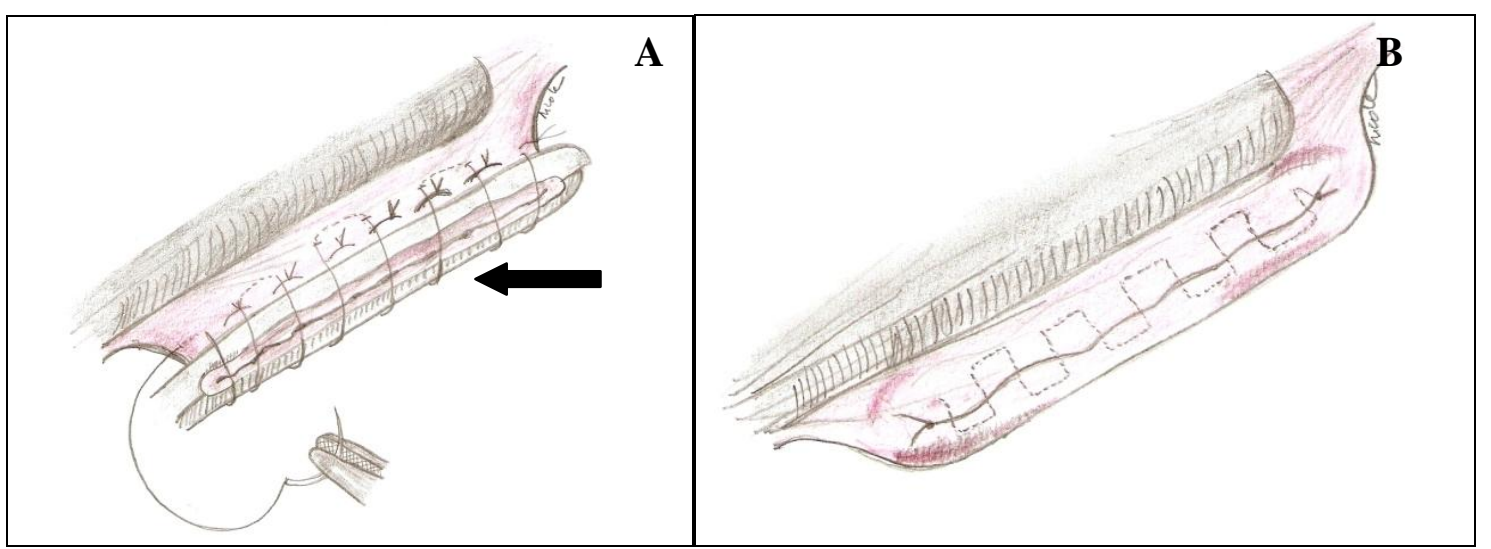

Figure 6. Illustrative drawing of the rectum, after resection of rectal sacculation. In A, Cushing suture is being completed, still with the presence of intestinal forceps (arrow). In B, suture finished after removal of forceps on a dog.

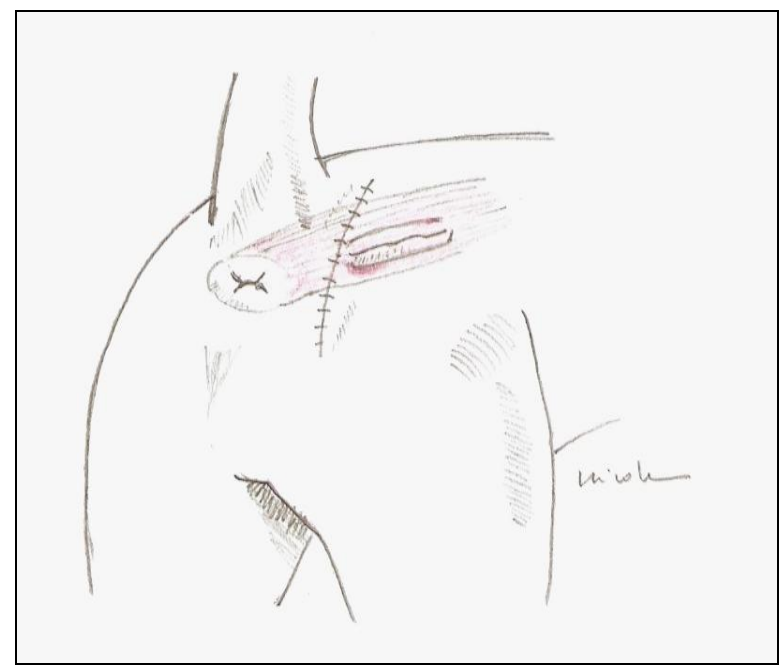

Figure 7. Illustrative drawing of a dog at the end of the surgical procedure. 


\section{RESULTS}

The postoperative care is the same as recommended for enterectomy. Therefore, the patient should be monitored, especially regarding feeding and surgical wound management.

During the first three days an exclusively liquid diet should be administered and the normal diet can be reintroduced gradually ten days after surgery. The surgical wound should be cleaned and treated with antiseptic solution every time the animal defecates. The use of intestinal lubricants such as mineral oil or Psyllium fiber are prescribed to avoid any effort in defecation. Stitches are removed after ten days and the animal can resume normal activities.

\section{DISCUSSION}

The occurrence of perineal hernia is frequent in the routine small animal clinical surgery. Referral of patients that were previously subjected only to a perineal herniorrhaphy and that exhibited rectal abnormality is also common. These animals remain with tenesmus and dyschezia since there was no complete resolution of the problem. In these cases, a second surgical intervention is necessary, which is prejudicial to the patient and complicated for the surgeon. Physical examination and radiographic studies are extremely important for a precise diagnosis (Bojrab and Toomey, 1981).

Some techniques for correction of rectal sacculation are described in literature (Costa Neto et al., 2006). Animals with diagnosis of rectal sacculation concomitant to perineal hernia and subjected to the technique described here did not exhibit recurrence since the causes of tenesmus and dyschezia were definitively corrected.

\section{CONCLUSION}

Taking into account the positive results achieved with the technique described, the objective of this report was to make a new alternative available for veterinary surgeons since the surgical access is similar to the traditional perineal herniorrhaphy.

\section{REFERENCES}

BELLENGER, C.R.; CANFIELD, R.B. Hérnia Perineal. In: SLATTER, D. (Ed), Manual de Cirurgia de Pequenos Animais. 2th. São Paulo: Manole, 1998. p.578-590.

BELLENGER, C.R.; CANFIELD, R.B. Perineal hernia. In: SLATTER D. (Ed), Textbook of small animal surgery. 3th. ed. Philadelphia: Saunders, 2003. p.487-498.

BOJRAB, M.J.; TOOMEY, A. Perineal herniorrhaphy. Compend Contin. Educ. Pract. Vet., v.8, p.8-15, 1981.

BURROWS, C.F.; HARVEY, C.E. Perineal hernia in the dog. J. of Small An. Pract., v.14, p.315-331, 1973.

COSTA NETO, J.M. et al. Tratamento cirúrgico de hérnia perineal em cão com saculação retal coexistente. Ver. Bras. Saude Prod. Anim., v.7, p.0719, 2006.

DEAN, P.W.; BOJRAB, M.J. Hérnia Perineal. In: BOJRAB, M.J. (Ed). Técnicas Atuais em Cirurgia Veterinária. 3.ed. São Paulo: Rocca, 1996. p.410-421.

DIETERICH, H.F. Perineal hérnia repair in the canine. Vet. Clin. North Am., v.5, p.383-399, 1975.

FERREIRA, F.; DELGADO E. Hérnias perineais nos pequenos animais. Rev. Port. Cienc. Vet., v.545, p.3-9, 2003.

FOSSUM W.T. Cirurgia de Pequenos Animais. São Paulo: Roca, 2008. p.1151.

HEDLUND, C.S. Perineal hernia. In: FOSSUM T.W. (Ed). Small animal surgery. 2th , St. Louis: Mosby, 2002. p.433-437.

KRAHWINKEL, D.J. Rectal diseases and their role in perineal hernia. Vet. Surg., v.12, p.160-165, 1983.

ORSHER, R.J. Analysis of results of internal obturator transposition. Vet. Surg., v.15, p.253-258, 1986.

SEIM III, H.B. Perineal hernia repair. In: WORLD CONGRESS IN SMALL ANIMAL VETERINARY MEDICINE, 29., 2004, Rhodes. Proceedings... Rhodes: Alta Gráfico Publisher, v.1, p.833-836.

SCHWARZ, T.; BIERY D.N. Large Bowel. In: THRALL D.E. (Ed). Textbook of veterinary diagnostic radiology. 5th ed. Missouri: Saunders Elsevier, 2007. p.792-802.

WELCHES, C.D.; SCAVELLI, T.D.; ARONSOHN, M.G. Perineal hernia in the cat: a retrospective study of 40 cases. J. Am. Anim. Hosp. Assoc., v.28, p.431$438,1982$. 